\title{
Çorum İli, Dodurga İlçesi Ağzında Geçen Bazı Kelimeler ve Bu Kelimelerin Dîvān-ü Lügāti’t Türk, Kutadgu Bilig ve Azerbaycan Türkçesindeki Varlığı Üzerine
}

\section{Some Words in the Dialect of Dodurga District of Çorum Province and On the Existence of These Words in Dîvān-ü Lügāti Türk, Kutadgu Bilig and Azerbaijan}

\author{
Sevinç Ahundova a, ${ }^{\mathrm{a}}$, Mustafa Töremiş ${ }^{\mathrm{b}}$ \\ a Öğr. Gör. Dr., Hitit Üniversitesi, Fen Edebiyat Fakültesi, Türk Dili ve Edebiyatı Bölümü, 19040, Çorum/Türkiye \\ ORCID: 0000-0001-9540-1517

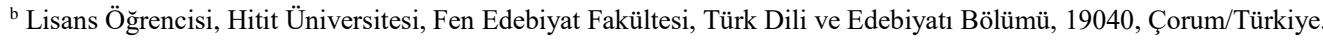 \\ ORCID: 0000-0002-8560-1168
}

\section{MAKALE BİLGİSI}

\section{Makale Geçmişi:}

Başvuru tarihi: 30 Eylül 2020

Düzeltme tarihi: 19 Ekim 2020

Kabul tarihi: 28 Ekim 2020

\section{Anahtar Kelimeler:}

Dodurga Ağzı,

Dîvān-ü Lügāti't Türk,

Kutadgu Bilig,

Azerbaycan Türkçesi

\section{ARTICLE INFO}

\section{Article history:}

Received 30 September 2020

Received in revised form 19 October 2020

Accepted 28 October 2020

\section{Keywords:}

Dodurga Dialect,

Dîvān-ü Lügāti'tTurk,

Kutadgu Bilig,

Azerbaijan Turkish
ÖZ

Çalışmamız "Çorum İli, Dodurga İlçesi Ağzında Geçen Bazı Kelimeler ve Bu Kelimelerin Dîvān-ü Lügāti’t Türk, Kutadgu Bilig ve Azerbaycan Türkçesindeki Varlığı Üzerine” dir. Dodurga ilçesi ağzında geçen eski ve günümüzde pek de yaygın olmayan fakat çağdaş Türk lehçelerinden Azerbaycan Türkçesinde aktif olarak kullanılan bu kelimeleri incelemeye ve karşılaştırmaya çalıştık. Bu kelimelerin tarihsel süreç içerisinde nasıl kullanıldığını, bunların Türkçenin bilinen ilk sözlügü olan Divān-ü Lügāti’t Türk'te ve Türkçenin önemli dil yadigârlarından olan Kutadgu Bilig'deki yerini tespit etmeğe çalıştık. Türkçenin hem de, Türk dili araştırmalarının ana kaynaklarından olan bu iki eser, bu araştırmamızda bize yol göstermiştir. Bu kelimelerin her iki eserdeki yerini varlıklarını, karşılıklarını ve semantik olarak benzerliklerini inceledik. Çalışma için esas olarak alınan iki temel kaynak bizlere oldukça yararlı olmuştur.

\section{A B S T R A C T}

Our study is "On Some Words in Çorum Province, Dodurga District and Their Presence in Dîvānü Lügāti Türk, Kutadgu Bilig and Azerbaijan Turkish". We tried to examine and compare these words that are used actively in Azerbaijani Turkish, which are old and not so common today, but one of the contemporary Turkish dialects in the dialect of Dodurga district. We tried to determine how these words were used in the historical process and their place in Divān-ü Lügāti, the first known dictionary of Turkish, and in Kutadgu Bilig, one of the important language heirlooms of Turkish. These two works, which are the main sources of Turkish as well as Turkish language research, guided us in this research. We examined the places, equivalents, and semantic similarities of these words in both works. Two main sources taken as a basis for the study have been very useful to us.

\section{Giris}

Atalarımızdan bizlere nakledilen ve bizlere kalan en güzel miras olan Türk dili bulunduğu dil ailesinde (Altay grubu) tarihi süreç içerisinde varlığını sürdürmektedir. Ziya Gökalp'ın deyişiyle “Güzel dil Türkçe bize, başka dil gece bize."
11. yüzyılda Kaşgarlı Mahmut tarafından yazılan ve Türkoloji’nin, Türklerin bilinen en eski sözlüğü ve eğitim kaynağı olan Dîvân-ü Lugâti't Türk'ün, Türk dili, kültürü ve tarihi açısından taşıdığı değer, önem, paha biçilmezdir. Dîvân-ü Lugâti't Türk, Araplara Türkçe öğretmek amacıyla Arapça-Türkçe (Karahanlı Türkçesi ile) şeklinde yazılmış Türk dilinin temel kaynaklarından sayılan bir eserdir.

\footnotetext{
* Sorumlu yazar/Corresponding author.

e-posta: sevincahundova@yahoo.com
} 
Öte yandan Yûsuf Has Hâcib tarafindan 11. yüzyılda yazılmış, Türk dilinin, edebiyatının ve kültür tarihinin en önemli kaynaklarından birisi de Kutadgu Bilig'dir. Türk yazı diline hâkim olan Yûsuf Has Hâcib eserini, seçmiş olduğu yarı hikâye yarı temsil tarzında, arada hareketi sağlayıcı ve açıklayıcı konuşmaların, canlı tasvirlerin süslemiş olduğu sahneleriyle mükemmel bir üslûp ve mimari çerçeve içine yerleştirmiştir.

İki temel kaynağı baz alarak ortaya koyduğumuz "Çorum İli, Dodurga İlçesi Ağzında Geçen Bazı Kelimeler ve Bu Kelimelerin Dîvān-ü Lügāti't Türk, Kutadgu Bilig ve Azerbaycan Türkçesindeki Karşılıkları Üzerine" isimli çalışmamızda günümüz Çorum İli, Dodurga İlçesi ağzında geçen bazı kelimeleri inceledik. Bu kelimelerin Türklerin bilinen en eski ve temel kaynaklarından olan Dîvân-ü Lügâti't Türk ve Kutadgu Bilig'de ve Oğuz grubu çağdaş Türk lehçelerinden olan Azerbaycan Türkçesinde de var olup olmadığına, zaman içerisinde nasıl değişikliklere uğradıklarına ve kullanımlarındaki benzerlik ve farklılıklarına, bu kelimelerin arkaik (unutulmuş) kelimeler olup olmadığına elimizden geldiğince değinmeğe çalıştık.

Eski zamanlara ait ve mevcut zamanlarda olmayan kullanılmayan kelimelerin tanımı olarak kullanılan “arkaizm', Türk Dil Kurumu'nun sözlügünde 'Konuşulan ve yazılan dilde kullanımdan düşmüş olan eski söz ve deyim, ayrıca kullanıldığı çağdan daha eski bir çağdan kalma bir biçimin bir yapının özelliğì olarak tanımlanmaktadır. Günümüzde çokça kullandığımız bazı kelimelerin (A ğsak, Enük, Edik, Kayır, Bıçkı, Bıldır ve Kak1-) birebir veya bir benzerini Dîvān-ü Lügāti’t Türk'te gördük. Yine bazı kelimelerin (Etükçü, İw-, Kayır, Segirt-, Yügür-) de tarihi süreç içinde çeşitli değişimlere uğrayarak Dîvān-ü Lügāti't Türk'te de, Kutadgu Bilig'de de görüldüğünü, hangi anlamlarda kullanıldığını incelemiş olduk. Ayrıca Azerbaycan Türkçesinde de bugün bu iki temel eserin kelime kadrosunda kullanılan birçok kelime aktif olarak kullanılmaktadır. Bu kelimeleri de ortaya çıkarmakla, bir nevi eski Oğuz Türkçesi olarak bilinen Azerbaycan Türkçesi ile ortaklıkları tespit ederek, arkaik olarak kabul gören unsurların çağdaş lehçelerde hala yaşadığını görmemiz Türkçe açısından elzemdir.

Böyle bir çalışmayı yapmamızdaki asıl amaç canlı bir varlık olan dilin zaman içerisindeki seyrini anlamaya çalışmaktır. Ayrıca dil, tarih ve kültür arasındaki bağlantı ve milli değerlerimizi bizlere yansıtan kelimelerin önemine de değinmek istedik.

\section{Dodurga İlçesi Ağzında Geçen Bazı Kelimeler}

\begin{tabular}{|c|c|}
\hline acıgerek & $\begin{array}{l}\text { mide rahatsızlığı sonucu geğirmek, ağızdan } \\
\text { gaz çıkarmak. }\end{array}$ \\
\hline acuk & yabanî, aşısız, meyve vermeyen elma ağacı. \\
\hline $\operatorname{ag}(\breve{g})$ uzba & çuval bağlamak için kullanılan ip. \\
\hline âğdırmak & ağır basmak, terazide dengesiz olmak. \\
\hline ağ1l & $\begin{array}{l}\text { büyükbaş ve küçükbaş hayvanların yatağı, } \\
\text { sığınmak için kullandıkları yer. }\end{array}$ \\
\hline ağnanmak & $\begin{array}{l}\text { 1) hayvanların özellikle (eşeklerin) toprak } \\
\text { üzerinde yatıp yuvarlanması. } \\
\text { 2) üzerine çullanmak, çökmek. }\end{array}$ \\
\hline âğsak-âsak & topal, aksak. \\
\hline alazlama & $\begin{array}{l}\text { 1) yarım, hafif pişirmek. } \\
\text { 2) ateşe odun atma eylem. }\end{array}$ \\
\hline âleşmek- & durmak, beklemek, gereksiz yere oyalanmak. \\
\hline
\end{tabular}

\begin{tabular}{|c|c|}
\hline \multicolumn{2}{|l|}{ e'leşmek } \\
\hline algun-algin & $\begin{array}{l}\text { gözenekli su yolu, arktan fark1 etrafinın } \\
\text { gözenekli olmasıdır. }\end{array}$ \\
\hline $\begin{array}{l}\text { anırmak }- \\
\text { anğılamak }\end{array}$ & eşeğin bağırması, ses çıkarması. \\
\hline badal-badel & merdiven basamakları. \\
\hline bandik & $\begin{array}{l}\text { köylerde, genellikle kadınların giydiği şalvar, } \\
\text { içlik. }\end{array}$ \\
\hline banma & $\begin{array}{l}\text { kışlık yiyecekler için, eskiden çamaşır } \\
\text { yıkamak için kullanılan büyük kazan ve } \\
\text { tencere. }\end{array}$ \\
\hline $\begin{array}{l}\text { beynemaz- } \\
\text { benamaz }\end{array}$ & $\begin{array}{l}\text { namaz kılmayan kimseler için kullanılan } \\
\text { tabir. }\end{array}$ \\
\hline bıçk1 & her türlü kesmeye yarayan alet. \\
\hline bildir & geçen yıl. \\
\hline bödelek & böbrek. \\
\hline cabcuk & şımarık, saygısız kimse. \\
\hline cibre & $\begin{array}{l}\text { üzümün ezildikten, suyu çıkarıldıktan sonraki } \\
\text { posası. }\end{array}$ \\
\hline culluk & hindi. \\
\hline çinek & $\begin{array}{l}\text { üzüm bağlarında biten burçaklı yapısıyla } \\
\text { yapışkan olan bir ot. }\end{array}$ \\
\hline çöğdürmek & $\begin{array}{l}\text { 1) çöğdürmek. } \\
\text { 2) erkek çocuklarının ayaktan tuvalet } \\
\text { ihtiyacını gidermesi, bebeklerin annelerinin } \\
\text { yardımıyla tuvalet yapması. }\end{array}$ \\
\hline çördük & $\begin{array}{l}\text { yabanî, aşısız, meyve vermeyen armut ağacı, } \\
\text { ahlat. }\end{array}$ \\
\hline edik & $\begin{array}{l}\text { ayakkabı, pabuç genellikle çocukların } \\
\text { ayakkabıları. }\end{array}$ \\
\hline $\begin{array}{l}\text { ellām - elle- } \\
\text { elleğem }\end{array}$ & herhalde, galiba, sanırsam, belki. \\
\hline ellüğün körü & elinin körü. \\
\hline essah & sahiden, gerçekten. \\
\hline enük & köpek ve köpek yavrusu. \\
\hline evmek & yapılan işte acele etmektir. \\
\hline gabgacak & tabak, çanak, tas. \\
\hline $\mathrm{g}(\mathrm{k})$ alan & $\begin{array}{l}\text { bundan sonra demek yerine söylenir. aslında } \\
\text { bulunduğu bağlamda "kalanı" şeklindedir. }\end{array}$ \\
\hline kayır & kalın kum. \\
\hline $\mathrm{g}(\mathrm{k})$ avsara & can, gönül (kavsaramdar). \\
\hline $\begin{array}{l}\mathrm{g}(\mathrm{k}) \text { öynüme } \\
\mathrm{k}\end{array}$ & $\begin{array}{l}\text { yanmak. güneşten yanan meyvelere de } \\
\text { göynümüş veya göynük meyve denir. }\end{array}$ \\
\hline $\mathrm{g}($ kayma $)$ & kâğıt para. \\
\hline goya sanki & sanki. \\
\hline hela & tuvalet, ayakyolu . \\
\hline hüşkü & artık, fazlalık. her türlü artık. \\
\hline $\begin{array}{l}\text { irgalmak - } \\
\text { irgalanmak }\end{array}$ & sallanmak, oyalanmak \\
\hline ilān-ileğen & leğen. \\
\hline ilistir & süzgeç. \\
\hline islah & $\begin{array}{l}\text { çok güzel anlamına gelen beğenme bildiren } \\
\text { ifade. }\end{array}$ \\
\hline $\begin{array}{l}\text { gakhımak - } \\
\text { kakımak }\end{array}$ & küsmek, darılmak. \\
\hline makat & $\begin{array}{l}\text { köy evlerinde s1k görülen,üzerinde oturmak } \\
\text { ve yatmak için (özellikle bel rahatsızlığ } \\
\text { olanların rahat yatması için) tahtadan } \\
\text { yapılmış somya,tahta divan. }\end{array}$ \\
\hline merziman & merdiven. \\
\hline $\begin{array}{l}\text { nalçaba- } \\
\text { naşraba }\end{array}$ & büyük su kabıdır. \\
\hline nasibetsüz & $\begin{array}{l}\text { münasebetsiz, ilgisiz, kaba, söz söylemeyi } \\
\text { bilmeyen kimse. }\end{array}$ \\
\hline soyka & $\begin{array}{l}\text { işsiz, güçsüz, laf dinlemeyen, yeri geldiğinde } \\
\text { şımaran kimse. }\end{array}$ \\
\hline $\begin{array}{l}\text { söğürtmek(s } \\
\text { egirtmek) }\end{array}$ & koşmak, koşuşmak. \\
\hline
\end{tabular}




\begin{tabular}{ll}
\hline $\begin{array}{l}\text { tevşinmek- } \\
\text { devşinmek }\end{array}$ & elinden geleni yapma, çalışıp, çabalama. \\
\hline tokaşak & $\begin{array}{l}\text { toplu. özellikle meyve ve sebzelerin bir arada, } \\
\text { bitişik yetişmesi. }\end{array}$ \\
\hline yarsimek & beğenmek, hoş bulmak. \\
\hline yaslāç & $\begin{array}{l}\text { ekmek veya hamur işini açmakta kullanılan } \\
\text { tahta. }\end{array}$ \\
\hline yatır & $\begin{array}{l}\text { genellikle mezar anlamında kullanıldı̆̆ } 1 \\
\text { âşikârdır. fakat 70 yaş üstü insanların bildiği } \\
\text { diğer anlamı ağaç gövdesi, özü. }\end{array}$
\end{tabular}

\section{Dîvân-üLügâti't Türk'te Geçen ve Dodurga İlçesi Ağzında Bulunan Kelimeler}

1) Halk ağzında "geğirmek, ağızdan gaz çıkarmak", daha da kötüsü bir müddet bunun devam etmesi olarak bilinen “Acıgerek" kelimesi açısından Dîvān-ü Lügāti’t Türk’te"kegir-" yani "geğirmek" geçmektedir.

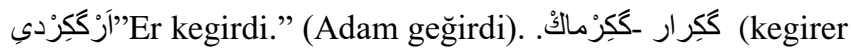
- kegirmek). ( ATALAY, 1985: 84)

2) "Aguzba" kelimesine karşsllk olarak Dîvān-ü Lügāti’t Türk’te "yıp" = "İp, tel, kendisiyle at bağlanan uzun örk" şeklinde geçmiştir.

"Bu yip ol eşilgen.” (Bu ip daima uzar). (ATALAY, 198:158.)

"Yıp": Kendisiyle at bağlanan uzunca örk. İp'ede يُبْ (yip) denir. (ATALAY, 1985:3.)

Ayrıca "yışı̆ kayışıve "uruk" = "İp, urgan" olarak da geçmektedir.

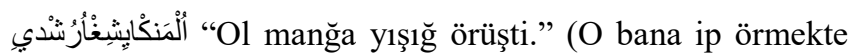
yardım etti). Herhangi bir şeyi örmekte yarışmak da

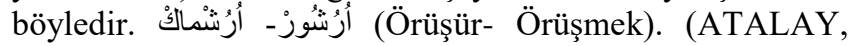
1985: 183)

أُرُقُق "Urk”: Uruk kelimesinin kısaltılmışıdır. (ATALAY, 1985: 42.)

3) “A şeklinde geçer anlam olarak koyun yatağı anlamını taşır. Ayrıca Oğuzlarca koyun pisliği anlamını da taşıdığı görülmektedir.

اغل "Aġıl”: Koyun yatağı. Oğuzlarca "koyun pisliği". (ATALAY, 1985:73)

4) "Ağnanmak" = Dîvān-ü Lügāti't Türk'te "ag̉namak" hayvanlar için yatıp debelenmek anlamında geçmiştir. İkinci bir anlamı ise "kekemeleşmek dili tutulmak" olarak geçmektedir.

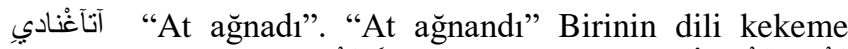

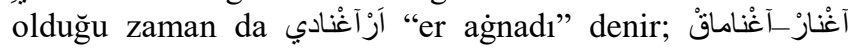
(Agnar - agnamak). Bu kelimenin aslı gunnelidir. (ATALAY, 1985: 289)

"Agnatmak" ise "hayvanları depelendirmek dili buruşturmak, dili ağırlaştırmak" şeklinde geçmiştir.

"Ol atın toprakka ag̉nattı." (O atını toprakta

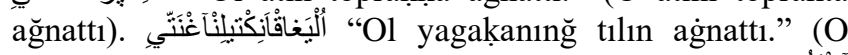
ceviz onun dilini buruşturdu, kekeme yapt1).- آَغْنَُّْ آَنْتَماق Agnnatur - Ag̀natmak). (ATALAY,1985: 267)
5) “Axsaḳ” (Ahsaḳ) (اخساق) = Dîvān-ü Lügāti’t Türk’te "ağsak, topal" şeklinde geçmektedir. [Axsamaḳ (Ahsamaḳ) , Axsatur (Ahssatur), Axsatmaḳ (Ahssatmaḳ) ]

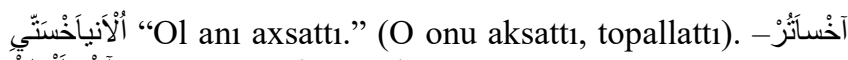
آَخْساَتْماقْ (Axsatur - Ahsatmak). (ATALAY, 1985: 262)

آخَسْاقُ Axsak: Aksak, topal. (ATALAY, 1985: 119)

Axsak - Buxsak (Ahsak - Buhsaḳ) Topal ve çolak olanlar için söylenir, iki kelime bir arada kullanılır. (ATALAY, 1985: 465)

6) "Añgılamak" Dîvān-ü Lügāti’t Türk’te "anırmak" şeklinde şu şekilde geçmiştir:

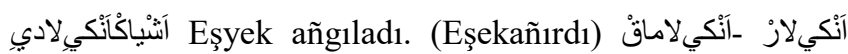
Anğılar - Anğılamak). (ATALAY, 1985: 311)

7) “Badal - Badel” kelimesi ise Dîvān-ü Lügāti't Türk’te "bag̉na" = "merdiven basamağı" şeklinde geçmektedir.

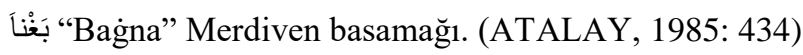

8) "Bıççı” Dîvān-ü Lügāti’t Türk’te "Bıçkı, Bıçguç" şekilleriyle geçmektedir. Anlamı kendisi ile herhangi bir şey kesilen nesnedir. Ayrıca Dîvān-ü Lügāti't Türk'te

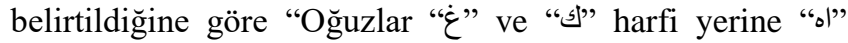

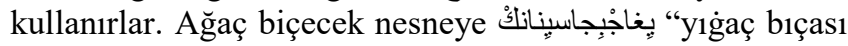
nenğ”. (ATALAY, 1985: 13)

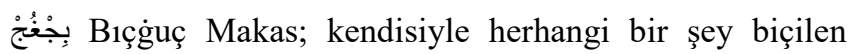
nesne. (ATALAY, 1985: 452)

Ayrıca Dîvān-ü Lügāti’t Türk’te "kesgü”, “Kesecek nesne." sözcüğü de geçmektedir.

كَنكُونانكأك "keskünenğ" Kesecek nesne. (ATALAY, 1985:13)

9) “Bıldır” (بلدر) Dîvān-ü Lügāti’t Türk’te “bıldır”, “geçen yıl” karşılığında kullanılmıştır.

"Bıldır” Bılldır, geçen yıl, bir yıldır. (ATALAY, 1985: 456)

10) Halk ağzında böbrekler için kullanılan "bödelek" tabiri yerine Dîvān-ü Lügāti’t Türk’te "böğrek, böbrek" anlamına gelen "bögür" sözcügü kullanılmıştır.

بُعُر "Bögür” : Böğür. (ATALAY, 1985: 361)

11) "Cabcuk" (şımarık, saygısız kimse) kelimesinin anlam olarak karşı1lığı Dîvān-ü Lügāti’t Türk’te “çabak er" (soysuz, mayası bozuk, sütsüz adam) şeklinde geçmektedir.

“Çabak er” Sosuz, mayası bozuk, sütsüz adam. (ATALAY, 1985:9)

12) "Culluk" kelimesi halk ağzında "hindi" olarak geçmektedir. Ancak Dîvān-ü Lügāti't Türk'te geçen "çulık", "çulluk, üveyik büyüklüğünde alacalı bir su kuşu" ile karıştırılmamalıdır.

جُلِقْ "Çulıḳ”: Üveyik büyüklüğünde alacalı bir su kuşu, çulluk. (ATALAY, 1985: 381)

13) “Çinek” Dîvān-ü Lügāti't Türk’te "çinek” kelimesi şu şekilde geçmektedir.

a) "Çikin" Üzüm bağlarında biten başaklı bir ottur, hayvanlara verilir.

b) "Çikin" İbrişim. "Çikin yıpı" yani "ibrişim teli”" şeklinde belirtilmiştir. (ATALAY, 1985: 414) 
14) “Edik” Dîvān-ü Lügāti’t Türk’te “edik, pabuç” şeklinde geçmiştir.

"Etük” Edik, pabuç. (ATALAY, 1985:68)

15) “Enük” (انك) Dîvān-ü Lügāti’t Türk’te arslan, sırtlan, kurt ve köpek yavrularına denir.

انك "Enük" Arslan, sırtlan, kurt ve köpek yavrularına denir. (ATALAY, 1985: 72)

Enüklemek - Eniklemek, yavrulamak.

Enüklenmek - Eniklenmek, yavru sahibi olmak.

إِنْانُُنْنْبي “İt enüklendi” (köpek enikledi, enik sahibi oldu). Enüklenür-Enüklenmek (ATALAY, 1985: 294, 308)

Ayrıca kalıp ifade olarak "kir itliğenügi" kilidin dişleri şeklinde de geçmektedir.

كِرِنْلِكْانَكي "kir itliğenügi” Kilidin dişleri. (ATALAY, 1985:72)

إِت “It": İt, köpek. (ATALAY, 1985:35)

16) “Ewmek" (فمك) Dîvān-ü Lügāti’t Türk'te "bir şeyin etrafinda koşuşmak, o iş için acele etmek, çabalamak" anlamındadır. (Ewişmek, Ewrişmek)

"Kişiler 1şḳa ewişdi. "Herkes işe koşuştu”.

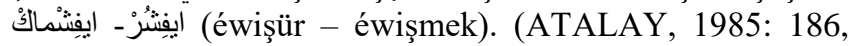
235)

Şu parçada geçmiştir:

Üdhü barıp öküş ewdim

Telim yorıp küçik evdim

Atım birle tegü ewdim

Meni körüp yini ağdı

(Ardınca varıp çok ivdim çok yorup kuvvetini gevşettim, atımla erişmeğe çabaladım, beni görerek tüyleri ürperdi). (ATALAY, 1985: 167)

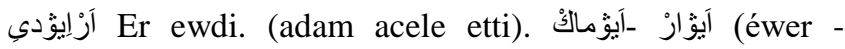
éwmek). (ATALAY, 1985: 183)

17) "Gab gacak" kelimesinin anlam olarak karşılığı ise iki şekilde Dîvān-ü Lügāti’t Türk’te şöyle geçmektedir:

a) "Kaḳaça" İçine akarlar konulan konan kap, kap kacak. (ATALAY, 1985: 211)

b) “Ayaḳ” (ايق) Kap ḳacaḳ. Bunu Oğuzlar bilmezler, onlar bu gibi şeylere "Çanaḳ”. (ATALAY, 1985: 84, 381)

( ) derler.

Ayrıca "idiş - idhiş" sözcüğü de "kadeh (Yağma, Toxsı, Yemek, Oğuz, Argu dillerinde) tas, bardak, tencere gibi her nevi kap" (ATALAY, 1985: 61)

18) “Irg̉almaḳ” (ارغلماق) Dîvān-ü Lügāti’t Türk’te "sallanmak, oyalanmak" şeklinde kullanılmıştır. (Irganmak, Irgalanmak)

"Yiğaç ırg̉ald1."”(A ğaç ırğaland1). Irgalanan her şey

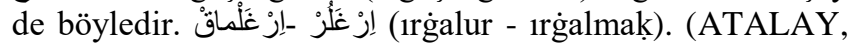
1985: 249)
19) "Kaḳ1-", "Gaḳ(h)1mak" - Birine k1zmak darılmak. (ḳaḳışur, ḳaḳış-).

"Eren ḳamuğ ḳaḳışdı”. (Adamlar birbirlerine kızıştılar, öfkelendiler).,

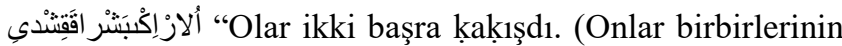

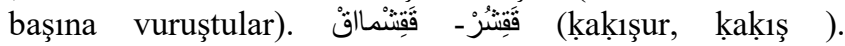
(ATALAY, 1985: 104)

"Kaḳı ğ-" Kakıma, kızma, istememe duygusu, rağmen.

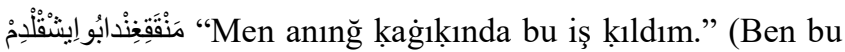
işi ona rağmen yaptım). (ATALAY, 1985: 376)

20) “Kayır” kelimesi Dîvān-ü Lügāti’t Türk'te Oğuzlarca "kum, O. Türklerce "kaba topraklı yer” olarak geçmektedir.

قَيقِ “Kayır” Türklerce "kaba topraklı yer”. Oğuzlar kuma "kayir" derler. (ATALAY, 1985: 165)

21) “Köynümek” Dîvān-ü Lügāti’t Türk’te “yanmak, yakmak" anlamlarında geçmektedir. (ATALAY, 1985: 187, 188)

Köyür- , "Yanmak, yaktırmak".

Köyük, "Yanmış, yanış".

"Er otunğ köytürdi”. (Adam odun yaktırd1) Başkası da böyledir. كُيُرُز -كُيُرْْ مالكَ (Köyürür- Köyürmek)

22) “G(K)ayma” Kâğıt para olarak halk ağzında geçen sözcüğe karş1lık Dîvān-ü Lügāti’t Türk’te Uygurca olan "yartmak, para" sözcüğü geçmektedir.

"Yartmaḳ” Para.Uygurca. (ATALAY, 1985: 432.)

23) "Hela" kelimesine karşılık olarak Dîvān-ü Lügāti’t Türk'te "çumuşluk" = "abdesthane, ayakyolu" geçmektedir.

جُجُشْنُقْْ "Çumuşluk”: Aptesane, ayakyolu. (ATALAY, 1985: 503)

24) Her türlü artık, çör çöp anlamına gelen "hüşkü" kelimesine karşıllık olarak Dîvān-ü Lügāti’t Türk’te “çöpik - şöbik" = çör çöp, meyve yenildikten sonra atılan şey" olarak geçmektedir. Fakat belirtelim ki Çorum ili Dodurga ilçesi ağzında meyve artığına "eşelek" denilmektedir.

ش شُ شُبكْ harfi ج den çevrilmiştir. (ATALAY, 1985: 390)

Ayrıca "yam" - "çerçöp, pislik, çapak" kelimesi de yine Dîvān-ü Lügāti’t Türk’te geçmektedir.

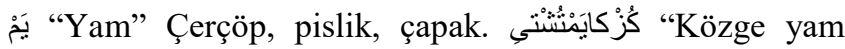
tüşti.” (Göze çöp düştü). (ATALAY, 1985: 5)

25) “Sittürmek” Dîvān-ü Lügāti’t Türk'te asl1 "sidhmek", "işemek, işetmek" olarak geçen kelime günümüz ağızlarında "çöğdürmek, çöğdürtmek" şeklinde kullanılmaktadır.

"Urag̉ut og̉lın sidhitti. (Kadın oğlunu işetti).

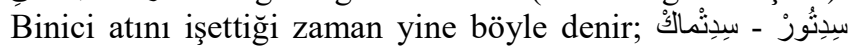
(sidhitür- sidhitmek). (ATALAY, 1985: 302)

ستُردنأغلنأل Ol oglın sittürdi. (O oğlunu işetti, siydirdi). Atını kaşandırırsa yine böyledir. Aslı "sidhtürdi”dir. İdgam

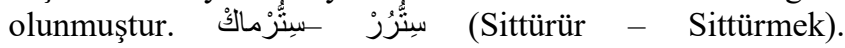
(ATALAY, 1985: 183) 
Er sidhti. (Adam işedi). Başkası da böyledir. Aslı

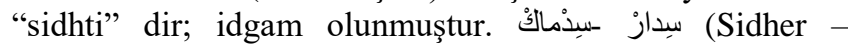
Sidhmek). (ATALAY, 1985: 295)

Ayrıca Dîvān-ü Lügāti’t Türk’te “çişe-” (çiş etmek) ve "çişet-" (çiş ettirmek) de geçmektedir.

“Og̉lan çişedi.” (Çocuk çişedi, çiş etti, pisledi). Bu kelime ancak küçüklerde kullanılır. (ATALAY, 1985: 267)

"Urag̉ut kençin çişetti.” (Kadin çocuğunu

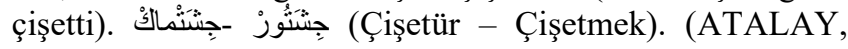
1985: 307)

26) "Söğürtmek" Dîvān-ü Lügāti’t Türk’te "segirtmek" şeklinde geçer "koşmak, koşturmak" anlamlarını karşılar. (Segre-, Segriş-)

“Ol meninğ birle segrişdi.” (O benimle hangimiz daha iyi sıçrıyoruz diye seğirtmekte, atlamakta yarışt1). (ATALAY, 1985: 225)

سكرتنتغرقلنبT1g̈raḳlanıp segirtti. (Yiğitlenip koştu). (ATALAY, 1985: 274)

Ayrıca Dîvān-ü Lügāti’t Türk’te”yüg(ü)r-” - “koşmak, geçmek, segirtmek" şeklinde geçmiştir.

“'Badar badar yügürdi." (Patır patır, ayağının sesi işitilerek geçti). (ATALAY, 1985: 360)

27) “Tewşinmek-Tewşünmek”(تفنشكك). Dîvān-ü Lügāti’t Türk'te çalışmak, çırpınmak anlamında kullanılmıştır.

Erışta telim tewşindi.(Adam işte çok çalıştı,

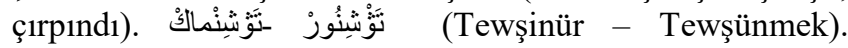
(ATALAY, 1985: 241)

28) "Yastı̇gaç" - Dîvān-ü Lügāti’t Türk’te “yasg̉aç” veya "yasdığaç" şeklinde geçer ve ekmek yapmak için kullanılan tahtadır, hamur tahtası. Aslı "yassı yı gaç̧" yani yassı tahtadir.

“بَنْغاجْ "Yasg̉aç" - "Yasdığaç, hamur tahtası". Asl1 "yass1 yı̉̇aç" tır, "yassı ağaç" demektir. (ATALAY, 1985: 38)

29) "Yatır” kelimesinin mezar anlamında karşılığg Dîvān-ü Lügāti't Türk’te "yerçü, sın mezar" şeklinde geçmektedir. Ayrıca Dîvān-ü Lügāti’t Türk’te mezar anlamına gelen "tuplu” sözcüğü de geçmektedir.

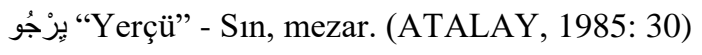

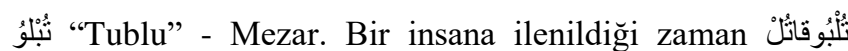
"Tulbuḳa tol" (Mezara gir). Demektir. (ATALAY, 1985: 430)

\section{Kutadgu Bilig'de Geçen ve Dodurga İlçesi Ağzında Bulunan Kelimeler}

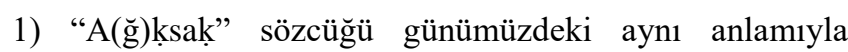
Kutadgu Bilig'de "aḳsaḳı ğ şeklinde geçmiştir.

Telim ögsüzüg kör ya tul tulsakı̆g

Ya közsüz ya oldrum yeme aḳsaḳığ (KAÇALİN, 2019: 172)

(Bak, burada birçok yetim, dul, aciz, kör, kötürüm ve topallar vardir).
2) “Gabkacak” kelimesine karşılık olarak Kutadgu Bilig'de "Ayaḳ" - "Çanak, kâse, hadek” sözcüğü geçmektedir.

Kirip ötrü tirki ayaḳ (KAÇALİN, 2019: 154) başlasa,

Anı̀dın begi aş séziksiz yése

(Böyle bir kimse sofra ve kapları idare eder ve beyi de ondan şüphe etmeden, yemeğini yiyebilir).

Ayaḳ (KAÇALINN, 2019: 242) tirki ev barḳarığtut töşek

Töşegil aş içgü yeme kedkerek

(Ev bark sofra ve tabakların temiz, odan minderlerle döşenmiş, yiyecek ve içeceklerin de seçkin olmalıdır).

3) "Enük" sözcüğüne karşılık olarak Kutadgu Bilig'de ise aynı anlama gelen "İt" sözcüğü kullanılmıştır.

Kimi ḳodtı erse ay ersigurı,

Kerek bolsun it (KAÇALIN, 2019: 320) kerek kök böri

(Ey cesur oğul, Tanrı onu terk ettikten sonra, ister köpek olsun, ister boz-kurt, hepsi birdir).

4) "Etükçü" - “Ayakkabııı" anlamına gelen bu kelimenin Kutadgu Bilig'deki varlığ "Edig” kelimesinin olduğunu ve "Etükçü" kelimesinin de şu şekilde meydana geldiğini açıklamaktadır. "Ayakkabıcı" (Edig $>$ Etük $>$ Etük + çi)

Açğıçı bitigçi ya iş tutğuçı,

Ya tonçı etükçi (KAÇALİN, 2019: 135) âmil bolğuçı

(Hazinedar veya kâtip gibi memurlar ve elbiseci veya ayakkabıcı gibi sanatkârlar ile münasebettedir).

Temürçi etükçi (KAÇALİN, 2019: 233) yana kırmaçı,

Ya sırçı bedizçi ya okçı yaçı

(Bunlar demirci, ayakkabıcı, derici yahut cilacı, boyacı veya okçu ve yayadır).

5) “İwmek" Bu kelime Kutadgu Bilig'de "acele etmek, koşmak, çırpınmak.” şeklinde geçmektedir.

İveklik (KAÇALİN, 2019: 111) belin ol ḳamuğḳa yavuz,

Kalı bolsa begke yüzi boldı boz

(Acelecilik her kes için fenadır ve derûnî bir korku neticesidir; eğer bu beyde olursa, onun yüzü kül renkli olur).

İwe (KAÇALİN, 2019: 111) ḳılmış işler neçe yég bolur,

İweyése aş suv neçe ig bolur

(Acele yapılan işler acı olur; acele yemek içmek yüzünden hastalık gelir).

6) "Kaḳ1-" sözcüğü Kutadgu Bilig'de Dîvān-ü Lügāti’t Türk'te geçen anlamından ziyade daha mecazi "kakılama" (hor görmek, aşağılamak) anlamlarına yakın bir anlamda kullanılmıştır.

Kaz ördek ḳuğu ḳalıḳığtudı

Kaḳılayu ḳaynar yoḳaru ḳodı (KAÇALİN, 2019:12)

(Kaz, ördek, kuğu ve k1l - kuyruk fezayı doldurdu; bağrışarak bir yukarı bir aşağı kaynaşıyorlar). 
7) “Kayır” Dîvān-ü Lügāti’t Türk’te geçtiği anlamını kaybetmeyerek Kutadgu Bilig'de de şu şekilde geçmektedir.

Kayır "Kum” (kalın veya ince). (ARAT, 1979: 230)

Ayrıca Kutadgu Bilig adlı eserin nüsha farklılıklarından dolayı "kayır" kelimesi Kutadgu Bilig'in nüshalarının metin kritiğinde ele alınmıştır. Bir nüshada bu kelime geçerken diğer nüshalarda farklı kelime ile görülmektedir.

Küdezdi nengin ked özin saḳladı

Tapındı ḳayır çaḳı yıḳḳılmadı. ${ }^{1}$

(Hükümdarın malını iyi idare etti, kendi çıkarını düşünmedi; hizmette kum kadar eğrilik göstermedi).

Küdezdi öziñ neñke suḳlanmadı

Tapundı bu ḳılça ḳıyık ḳılmadı (KAÇALİN, 2019: 97)

(Hükümdarın malını iyi idare etti, kendi çıkarını düşünmedi; hizmette k1l kadar eğrilik göstermedi).

Bu sözcük için yer yer Kutadgu Bilig adlı eserde "ḳum" sözcüğü de doğrudan doğruya geçmektedir.

Kuruğ kumka okşar bu yalñu közi (KAÇALİN, 2019:191)

Ögüz kirse todmaz bu sukluk közi

(Bir insan kuru kuma benzer, onun tamahkâr gözü derya girse doymaz).

8) "Segirtmek" kelimesine karşılık Kutadgu Bilig'de aynı anlama gelen şu kelime sık sık kullanılmıştır "Yügürmek".

Kayu tağda yügrür ünürde evi, (KAÇALİN, 2019:338)

Yemi ot köki içgü yağmur suvı

(Biri dağda koşar, evi mağaradır; onun yediği ot kökü, içtiği yağmur suyudur).

Bayat tapğı ḳaldı kişi tapğı kıldım,

Ajun tegre yügrü özümni kürettim

(İnsanlara hizmet ettim, Tanrı ibadeti kaldı; dünya etrafında koşarak, yolumu azıttım).

\section{Dodurga İlçesi Ağzında, Divanü Lügat’t Türk ve Kutadgu Bilig'de Geçen Geçen Kelimelerin Azerbaycan Türkçesindeki Şekilleri}

Bilindiği üzere Oğuz Grubu Türk Lehçelerinden olan Azerbaycan Türkçesi bugün Türkiye Türkçesi ile sadece anlaşılabilirliği açısından değil, aynı zamanda kelime kadrosu, şekil bilgisi, ses bilgisi yönünden de benzerlikler arz etmektedir. Bunun yanında, benzerliklerle beraber ses ve şekil değişimleri gibi farklılıklar da söz konusudur. Bu farklar zaman içerisinde değişime uğramış kelimelerde kendisini göstermiştir. Bu kelimelerin bazları arkaik unsur gibi görünse de bazıları Anadolu Ağızlarında hala yaşamaktadırlar. Anadolu ağızlarında bulunan birçok kelimeler Tarihi Türk Lehçelerinden olan Eski Anadolu

(DORUK, Muhammet, Kutadgu Bilig Viyana, Fergana, Kahire
Nüshalarının https://www.academia.edu/13403336/Kutadgu_Bilig_A_BC_NC3\%BCsha lar\%C4\%B1n\%C4\% 1n_Edisyon_kriti\%C4\%9Fi)
Türkçesi döneminin kelime hazinesinde de mevcut olmuştur. Azerbaycan Türkçesinde de, Eski Anadolu Türkçesinin ve bugün Anadolu'da konuşulan ağız, şekil, ses özelliklerinin devam ettiği bilinmektedir. Ele aldığımız konuya baktığımız zaman bunu açıkça görebilmekteyiz. Dodurga Ağzında, Dîvān-ü Lügāti’t Türk’te ve Kutadgu Bilig eserlerinde var olan ortak kelimelerden bazılarının Azerbaycan Türkçesinde de hala aktif bir şekilde varlığ sürmektedir. Aşağıdaki tabloda hem Dodurga Ağzında, hem Dîvān-ü Lügāti't Türk'te ve Kutadgu Bilig'de, hem de Azerbaycan Türkçesinde geçen ortak kelimeleri ele almaya çalıştık.

"Acıgerek" kelime itibariyle tam olarak Azerbaycan Türkçesinde geçmese de, "geyir - , geyirme, geyirti" şekilleri ile aktif olarak kullanılmaktadır.

"Ağnanmak" Kelime Azerbaycan Türkçesinde birinin üzerine doğru gerinmek anlamını ifade etmektedir. Şekil olarak "ağnamak" gibi geçmektedir.

"Âğsak-Âsak" kelimesi de Azerbaycan Türkçesinde "Ahsag Ahsag" şekliye ve "Aksak" anlamıla kullanılmaktadır.

“Âleşmek-Eleşmek” kelimesi bugün Türkiye Türkçesinde az kullanılan kelimeler arasında yer almaktadır. Ağızlarda görülmektedir. Azerbaycan Türkçesinde çok sık kullanılmaktadır. "Eyleş _" fiili bugün “Otur -" anlamında sıkça kullanılan bir kelime olarak görülmektedir.

"Anırmak - Anğılamak" fiili de Azerbaycan Türkçesinde aktif kullanılan fiiller arasındadır. "Angırmag" fiili 1 . Hayvan sesini ifade eden fiil olarak, 2. İnsana hitaben kullanıldığ 1 zaman aşağılama, hakaret ifadesini taşımaktadır.

"Badal-Badel" kelimesi Azerbaycan Türkçesinde "Pedal" şeklinde kullanılmaktadır. Kelimenin kullanımı sırasında "bisiklet pedalı, araba pedalı, piyano pedalı" gibi anlamlar ifade ettiği görülmektedir. Aynı zamanda kelimenin Rusça'da da var olduğu görülmektedir.

"Beynemaz-Benamaz" kelime Azerbaycan Türkçesinde "binamaz" şeklinde kullanılmakta "namazsı, dinsiz, imansız, beceriksiz" anlamlarını taşımaktadır.

"Bıldır" kelimesi Azerbaycan Türkçesinde "bildir" şekliyle geçmektedir. Anlam itibariyle "geçen yıldan bir önceki yıl" anlamını taşımaktadır.

"Bödelek" kelimesi Azerbaycan Türkçesinde "böyrek" şekliyle ve "böbrek" anlamılla bulunmaktadır.

"Çöğdürmek" fiili Azerbaycan Türkçesinde "çökdürmek, çömeltmek" şekliye bulunmaktadır.

"Enük" kelimesi de Azerbaycan Türkçesinde "enik", "köpek yavrusu" anlamıyla geçmektedir.

"Gabgacak" kelimesi Azerebaycan Türkçesinde aktif kullanılan kelimelerdendir. "Gabgacag" şeklinde ve "Kapkacak" anlamıyla bulunmaktadır.

"G(K) öynümek" fiili Azerbaycan Tükçesinde "göynemek" şeklindedir. "Yanmak, sızıldamak, ağrımak" anlamlarını taşımaktadır. 
“Goya, sanki” edatı Azerbaycan Türkçesinde "guya, sanki” şekliyle mevcuttur. Anlam itibariyle Türkiye Türkçesindeki anlamı karşılamaktadır.

"Hela" kelimesi Azerbaycan Türkçesinde "hela" şeklinde bulunmaktadır. "Tuvalet" kelimesinin karşılığını vermektedir.

"Irgalmak - Irgalanmak" kelimesi Azerbaycan Türkçesinde kelime başında " $y$ " türemesi ile geçmektedir. "Yırğalamag, yırğalanmag" şekliyle mevcuttur. Anlam itibariye "sallamak, sallanmak" manasını taşımaktadır.

"İlān-İleğen" kelimesi Azerbaycan Türkçesinde "leyen" şekliye geçmektedir. Anlam itibariyle de Türkiye Türkçesinde geçtiği anlamı ifade etmektedir.

"Gakhımak -Kakımak" bu fiil Azerbaycan Türkçesinde “gahmag” şekli ve "kakmak” anlamıyla geçmektedir.
"Merziman" kelimesi Azerbaycan Türkçesinde "nerdivan" şekliyle bulunmaktadır.

"Soyka" kelimesi bugün Anadolu ağızlarında var olup fazla kullanılmayan arkaik durumda bir kelimedir. Kelime Azerbaycan Türkçesinde "soha" şeklinde geçer ve sık kullanılmaktadır. Kızgınlık ifade eder.

"Söğürtmek (Segirtmek)" kelimesi "seyirmek, seyirtmek" şekliyle Azerbaycan Türkçesinde bulunmaktadır. "Göz seyirmesi” gibi örneklerle kelime açıklanabilmektedir.

“Tevşinmek-Devşinmek” kelimesinin şekilsel olarak karşılığı Azerbaycan Türkçesinde "tövşü -, tövşün - " dir. Anlam itibariyle "nefes nefese kalmak, koşuşturmak" manalarını taşımaktadır.

\begin{tabular}{|c|c|c|c|}
\hline Dodurga İlçesi Ă̆ğ & Türkiye Türkçesindeki Anlamı & DLT'deki Şekli & Azerbaycan Türkçesindeki Şekli \\
\hline acıgerek & $\begin{array}{l}\text { mide rahatsızlığı sonucu } \\
\text { geğirmek. }\end{array}$ & kegirmek, geğirmek. & geyirmek, geyirme. \\
\hline acuk & $\begin{array}{l}\text { yabanî, aşısız, meyve vermeyen } \\
\text { elma ağacı. }\end{array}$ & & \\
\hline $\operatorname{ag}(\breve{g})$ uzba & $\begin{array}{l}\text { çuval bağlamak için kullanılan } \\
\text { ip. }\end{array}$ & $\begin{array}{l}\text { yıp, yışı̆g, uruk - ip, } \\
\text { urgan. }\end{array}$ & ip. \\
\hline âğdırmak & $\begin{array}{l}\text { ağır basmak, terazide dengesiz } \\
\text { olmak. }\end{array}$ & & \\
\hline ağıl & $\begin{array}{lcc}\text { büyükbaş ve } & \text { küçükbaş } \\
\text { hayvanların } & \text { yatağı, } & \text { sığınmak } \\
\text { için kullandıkları yer. } & \\
\end{array}$ & ağıl & \\
\hline ağnanmak & $\begin{array}{l}\text { 1) hayvanların özellikle } \\
\text { (eşeklerin) toprak üzerinde } \\
\text { yatıp yuvarlanması. } \\
\text { 2) üzerine çullanmak, çökmek. }\end{array}$ & aġnamak & ağnanmag, ağnamag. \\
\hline âğsak-âsak & topal & axsak, ahsak, ağsak & axsag, topal. \\
\hline alazlama & $\begin{array}{l}\text { 1) yarım, hafif pişirmek. } \\
\text { 2) ateşe odun atma. }\end{array}$ & & \\
\hline âleşmek-e'leşmek & $\begin{array}{l}\text { durmak, beklemek, gereksiz } \\
\text { yere oyalanmak. }\end{array}$ & & eyleşmek, oturmak, yerleşmek \\
\hline algun-algin & $\begin{array}{l}\text { gözenekli su yolu, arktan fark1 } \\
\text { etrafının gözenekli olmasıdır. }\end{array}$ & & \\
\hline anırmak & $\begin{array}{l}\text { eşeğin bağırması, } \\
\text { çıarması. }\end{array}$ & añgılamak, anırmak. & anq1rmaq, angırma \\
\hline badal-badel & merdiven basamakları. & baġna & $\begin{array}{l}\text { pedal (araba,bisiklet, piyanoda } \\
\text { bulunan pedal) }\end{array}$ \\
\hline bandik & kadınların giydiği şalvar, içlik. & & \\
\hline banma & $\begin{array}{l}\text { kışlık yiyecekler için, eskiden } \\
\text { çamaşır yıkamak için kullanılan } \\
\text { büyük kazan } \\
\text { tencere. }\end{array}$ & & \\
\hline beynemaz-benamaz & $\begin{array}{l}\text { namaz kılmayan kimseler için } \\
\text { kullanılan tabir. }\end{array}$ & & binamaz \\
\hline bıçk1 & her türlü kesmeye yarayan alet. & bıçġ̀, bıçġuç, kesgü & \\
\hline bildir & geçen y1. & bildır, geçen yil & $\begin{array}{l}\text { bildir (geçen y1l ve geçen yıldan } \\
\text { bir önceki önceki yıl) }\end{array}$ \\
\hline bödelek & böbrek & bögür, böğrek. & böyrek \\
\hline cabcuk & Şımarık, saygısız kims. & çabak er. & \\
\hline cibre & $\begin{array}{l}\text { üzümün ezildikten, suyu } \\
\text { çıarıldıktan sonraki posası. }\end{array}$ & & \\
\hline culluk & hindi. & çulık, çullu. & \\
\hline çinek & $\begin{array}{l}\text { üzüm bağlarında biten burçaklı } \\
\text { yapısıyla yapışkan olan bir ot. }\end{array}$ & çikin, ibrişim. & \\
\hline çöğdürmek & $\begin{array}{l}\text { 1) çöğdürmek. } \\
\text { 2) erkek çocuklarının ayaktan } \\
\text { tuvalet ihtiyacını gidermesi, } \\
\text { bebeklerin }\end{array}$ & sittürmek, sidhmek. & $\begin{array}{l}\text { çömeltmek, siydirmek } \\
\text { (büyük abdestini yaptırmak) }\end{array}$ \\
\hline
\end{tabular}


yardımıyla tuvalet yapması.

\begin{tabular}{|c|c|c|c|c|}
\hline çördük & $\begin{array}{l}\text { yabanî, aşısı, meyve vermeyen } \\
\text { armut ağacı, ahlat. }\end{array}$ & & & \\
\hline edik & $\begin{array}{l}\text { ayakkabı, pabuç genellikle } \\
\text { çocukların ayakkabıları. }\end{array}$ & etük, edik. & etükçi & \\
\hline ellām-elle-elleğem & $\begin{array}{l}\text { herhalde, galiba, sanırsam, } \\
\text { belki. }\end{array}$ & & & \\
\hline ellüğün körü & elinin körü. & & & \\
\hline essah & sahiden, gerçekten. & & & \\
\hline enük & $\begin{array}{l}\text { köpek ve köpek yavrusu için } \\
\text { kullanılan sözcüktür. }\end{array}$ & enük & it & enik \\
\hline evmek & $\begin{array}{l}\begin{array}{l}\text { yapılan } \\
\text { ivedilik }\end{array} \\
\end{array}$ & ewişmek, ewrişmek & iveklik & \\
\hline gabgacak & tabak, çanak, tas. & kakaça, ayak & $\begin{array}{l}\text { ayak - çanak, } \\
\text { kase. }\end{array}$ & gabgacag \\
\hline $\mathrm{g}(\mathrm{k})$ alan & 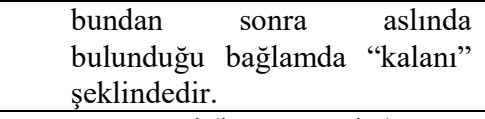 & & & galan, galanı. \\
\hline $\mathrm{g}(\mathrm{k})$ avsara & can, gönül (kavsaram dar). & & & \\
\hline $\mathrm{g}(\mathrm{k})$ öynümek & $\begin{array}{l}\text { yanmak demektir. halk arasında } \\
\text { olgunlaşt1ktan sonra güneşten } \\
\text { yanan meyvelere de göynümüş } \\
\text { meyve denir. }\end{array}$ & köynümek, köyürmek & & göynemek \\
\hline g(kayma) & kâğıt para demektir. & yartmak & & \\
\hline goya sanki & sanki. & & & guya, sanki. \\
\hline hela & tuvalet, ayakyolu. & cumuşluḳ & & \\
\hline hüşkü & her türlü artık, fazlalık. & çöbik, şöbik. & & \\
\hline ilān-ileğen & leğen. & & & leyen. \\
\hline ilistir & süzgeç. & & & \\
\hline islah & $\begin{array}{l}\text { çok güzel anlamına gelen } \\
\text { beğenme bildiren ifade. }\end{array}$ & & & \\
\hline 1rgálmak & & 1rganmak, 1rgalanmak & & yırğalanmag, yırğalamag \\
\hline kakımak & küsmek, darılmak. & kakıımal, gaḳımak & kakı1lamak & gahmag \\
\hline kayır & kalın kum demektir. & kayır, kum. & $\begin{array}{lr}\text { kayır- } & \text { kalın } \\
\text { veya } & \text { ince } \\
\text { kum. } & \\
\end{array}$ & \\
\hline makat & $\begin{array}{l}\text { köy evlerinde s1k görülen, } \\
\text { üzerinde oturmak ve yatmak } \\
\text { için (özellikle bel rahatsızlığı } \\
\text { olanların rahat yatması için) } \\
\text { tahtadan yapılmış somya, tahta } \\
\text { divan. }\end{array}$ & & & \\
\hline merziman & merdivan. & & & nerdivan \\
\hline nalçaba-naşraba & büyük su kabı. & & & \\
\hline nasibetsüz & $\begin{array}{l}\text { münasebetsiz, ilgisiz, kaba, söz } \\
\text { söylemeyi bilmeyen kimse. }\end{array}$ & & & \\
\hline soyka & $\begin{array}{l}\text { işsiz, güçsüz, laf dinlemeyen, } \\
\text { yeri geldiğinde şımaran kimse. }\end{array}$ & & & soxa (k1zgınlık bildirir) \\
\hline $\begin{array}{l}\text { söğürtmek } \\
\text { (segirtmek) }\end{array}$ & koşmak, koşuşmak. & segirtmek & yügürmek & \\
\hline tokaşak & $\begin{array}{l}\text { toplu. özellikle meyve ve } \\
\text { sebzelerin bir arada, bitişik } \\
\text { yetişmesine denir. }\end{array}$ & & & \\
\hline $\begin{array}{l}\text { tevşinmek } \\
\text { devşinmek }\end{array}$ & $\begin{array}{l}\text { - elinden geleni yapma, çalışıp, } \\
\text { çabalama. }\end{array}$ & $\begin{array}{l}\text { tewşinmek, tewşünmek } \\
\text { çalışmak, çırpınmak) }\end{array}$ & & tövşümek (nefes nefese kalmak) \\
\hline yarsimek & beğenmek, hoş bulmak. & & & \\
\hline yaslāç & $\begin{array}{l}\text { ekmek veya hamur } \text { işini } \\
\text { açmakta kullanılan tahta. }\end{array}$ & yasġaç, yasdıġaç & & \\
\hline yatır & $\begin{array}{l}\text { genellikle mezar anlamında } \\
\text { kullanıldığı aşikârdır. fakat } 70 \\
\text { yaş üstü insanların bildiği diğer } \\
\text { anlamı ağaç gövdesi, özü. }\end{array}$ & yerçü, sın, tuplu & & \\
\hline
\end{tabular}




\section{Sonuç}

Bir milletin tarih sahnesine çıkışından itibaren varlığını ve devamlılığını sağlamasında şüphesiz dil önemli ölçüde rol oynar. Bu yüzdendir ki, geçmişte kullanılan kelimeler bizim varlığımız, kültürel genlerimizdir. $\mathrm{Bu}$ kelimeler, kullanıldığ1 dönemden sonra da tarihsel süreç içinde varlığını sürdürmüş, unutulan (arkaik) kelimeler olsa da gelecek kuşaklara ağızlarda yaşatılarak aktarılmıştır. Tabii ki, bu aktarılma sürecinde çeşitli değişikliklere uğrasa da farklı şekillere giren kelimeler de vardır.

Yapılan araştırma ve inceleme sonucunda metaforik olarak yaşayan bir organizmaya benzetebileceğimiz dilin, milletin kültürel değerlerini; kelimeler, atasözleri, deyimler ve tabirleri tarihi süreç içinde sımsıkı muhafaza ettiğinin bir daha şahidi olduk. Muhafaza edilemeyen kısımların ise tarihi süreç içinde çeşitli ses olayları sonucu değişime uğradığı gözlemlenir. "Çorum İli, Dodurga İlçesi Ağzında Geçen Bazı Kelimeler ve Bu Kelimelerin Dîvān-ü Lügāti’t Türk, Kutadgu Bilig ve Azerbaycan Türkçesindeki Varlığı Üzerine" isimli çalışmamızda görüldüğü üzere Türk milletinin en eski sözlüklerinde var olan kelimelerin birebir günümüzde kullanıldığı çok açık ve nettir. Bunun yanı sıra Azerbaycan Türkçesinde de bazı kelimelerin yaşadığını gözlemledik.

Çalıştığımız eserlerdeki bu kelimelerinin bazıları bugün arkaik durumdadır. Anadolu ağızlarını incelediğimiz zaman görüyoruz ki bu kelimeler ses başı, ses ortası fonetik bazı değişimlerle günümüzde varlıklarını sürdürmektedirler. Çalışmamızda tespit ettiğimiz kelimelerde yukarıda söylediğimiz husus apaçık kendini kanıtlamıştır.

\section{Kaynakça}

Arat, R. R. (1959). Kutadgu Bilig II Tercüme, Ankara: Türk Tarih Kurumu.

Arat, R. R. (1979). (neşre hazırlayanlar: Kemal Arslan. O.F. Sertkaya, N. Yüce), Kutadgu Bilig III İndeks, İstanbul: TKAE. Yayımları.

Arat, R. R. (1999). Kutadgu Bilig I Metin, Ankara: Türk Dil Kurumu Yayınları.

Atalay, B. (1985). Dîvān-ü Lügāti’t Türk Tercümesi, Ankara: Türk Dil Kurumu Yayınları.

Gösterir, İ. (2009). Örnekli-Tanıklı Çorum Ağzı Sözlüğü, Çorum: Çorum Belediyesi Kültür Yayını.

Gülsevin, G. (2006). Kutadgu Bilig Türkçesinden Anadolu Ağılarına, Sosyal Bilimler Enstitüsü Dergisi S. 2006/1, S. 109-121

Günşen, A. (2000). Kırşehir ve Yöresi Ağıları (İncelemeMetin-Sözlük), Ankara: Türk Dil Kurumu Yayınları.

Kaçalin, M. S. (2019). Kutadğu Bilig Metin, İstanbul: T. C. Kültür ve Turizm Bakanlığı Kütüphaneler ve Yayımlar Genel Müdürlüğü.

Üşenmez, E. (2014). Eski Anadolu Türkçesinde Arkaik (Eski) Öğeler, İstanbul: Akademik Kitaplar Yayınevi.

Yoksul, C. (2013). Çorum Yöresi Sözlü Kültürü, Çorum: Çorum Belediyesi Kültür Yayınları. 